\title{
ANÁLISE IMAGÉTICA DA REVISTA CHANAAN
}

Luiza Avelar Moreira

Universidade Federal do Espírito Santo

luiza.avelarmoreira@gmail.com

Júlia Sousa Azerêdo

Universidade Federal do Espírito Santo

juliazeredodi@gmail.com

Letícia Pedruzzi Fonseca

Universidade Federal do Espírito Santo

Leticia.fonseca@ufes.br

Resumo: A presente pesquisa apresenta resultados da análise imagética da revista Chanaan, que observou suas trinta e duas edições, contribuindo para os estudos da memória gráfica capixaba. Foi publicada entre 1936 e 1939, na cidade de Vitória, Espírito Santo, Brasil, sob a direção de Carlos Madeira. O periódico apresentava o retrato da vida local durante um período de grandes transformações políticas e socioeconômicas no Estado (Achiamé, 2010). Foi uma revista direcionada a elite capixaba, possuindo matérias redigidas em inglês, espanhol e francês. Segundo informações contidas na própria revista, alcançou público em diversas capitais brasileiras e até fora do país. Com base nos resultados da pesquisa sobre uso da tipografia na revista realizada anteriormente, percebeu-se que a Chanaan é uma rica fonte de recursos visuais em sua composição, com recorrente uso de elementos imagéticos (Azerêdo et al, 2015). O laboratório possui o acervo digitalizado e catalogado. O levantamento dos dados se deu por meio de ficha de coleta que teve como objetivo captar características das imagens presentes no miolo e na capa. A classificação teve como base três tipos de imagens: fotografia, fotomontagem e ilustração. Após esta etapa foi inciada a tabulação digital de dados, tornando possível gerar gráficos e entender o comportamento dos elementos imagéticos ao longo da publicação. Na capa da revista havia os três tipos de imagens citados, sendo a fotografia mais frequente, presente em dezenove edições, seguida das ilustrações e fotomontagens. Estas imagens na maioria das vezes exibiam personalidades, datas comemorativas, paisagens e monumentos históricos. As imagens foram constantemente utilizadas no miolo, chegando a 128 por edição e fizeram parte de experimentações da revista Chanaan ao longo de sua produção. Foram observadas fotografias coloridas e em preto em branco, que representavam personalidades, eventos, pontos turísticos e o 
desenvolvimento do Estado. Muitas vezes essas fotografias possuíam formatos variados, com recorte circular e arranjos diversos. As fotomontagens eram frequentes na revista, como forma de fotorreportagem, muitas vezes acompanhadas por tipografias, ilustrações, símbolos geométricos e fios. Nessas fotomontagens eram apresentadas, principalmente, pontos turísticos, eventos e notícias sobre Estado. A Chanaan também fazia uso de ilustrações pictóricas, constantemente utilizadas como vinhetas, que interagiam com o título e o texto, e possuía ainda caricaturas. Estas ilustrações variavam entre o preto e branco e eram construídas só com traço ou com preenchimento. Os resultados apresentados neste estudo exibem como a revista Chanaan ao longo de seus quatro anos de publicação investiu em experimentações com seus elementos imagéticos, buscando alcançar um ar de modernidade que acompanhava as tendências gráficas do país em 1930. Este estudo é de grande importância para a construção da memória gráfica capixaba, visto que estes resultados são o reflexo de um período histórico e nos permite traçar um perfil que faz parte da produção impressa no estado do Espírito Santo na época.

Palavras-chave: design; memória gráfica; imagens; revista; Espírito Santo 